Global Conferences Series:

Social Sciences, Education and Humanities (GCSSSEH), Volume 3, 2019

The $1^{\text {st }}$ International Conference on Education, Social Sciences and Humanities

DOI: https://doi.org/10.326/hum0204

\title{
Human Rights Perspective in The Law of Legal Products in Indonesia
}

\section{Sri Rejeki ${ }^{1}$, Siti Hasanah ${ }^{2}$}

${ }^{12}$ Universitas Muhamadiyah Mataram

(*) $₫$ umi.cici.66@gmail.com

\begin{abstract}
This study aims to analyze descriptively about the recognition and protection of human rights that are actually actualized in legal products in Indonesia. The research approach is normative juridical so that the approaches to be used are: statute approach, conceptual approach, comparative approach, historical approach, based on the results of analysis it can be concluded that human rights are basic rights possessed by every human being, human rights are not gifts and gifts that can be seized and revoked, even though someone has acted ruthlessly and cruelly, but these basic rights cannot be carried out freely and totally in all matters, because these basic rights are also limited by the individual rights of others. The boundaries are made in the form of formal legal rules which are the main task of the legislature.The legal product in Indonesia is one of the legislative products.The main actor determining the color of law is the legislative member must be composed from selected people and quality so $\mathrm{m}$ able to carry out the functions and duties properly. At present ideal conditions are still far from expectations, this is due to various internal and external factors related to the institution. The future system of legislative recruitment must be improved so that it is able to realize the ideals of the people of Indonesia and be able to create quality legal products that are in harmony with the expectations and aspirations of the people.
\end{abstract}

Keywords: human rights, legal products

\section{Introduction}

Human rights are basic rights or natural rights that are owned by every human being since the womb, and because of that rights cannot be removed or deleted by anything and anyone except by the will of Allah SWT the Creator. No matter how bad the treatment has been experienced by someone or no matter how cruel the treatment of a person is, it will not stop being a human being and therefore he still has those rights[1]. Regarding this right Feinberg stated[2]

Copyright $(\odot$ 2019, the Authors. Published by Redwhite Press.

Page | 106

This is an open access article under the CC BY-NC license

(http://creativecommons.org/licenses/by-nc/4.0). 
Indispensablyvaluable possision, A world wthout them, no metter how full of benevolence and devotion to duty, would suffer an immanse moral inpoverishment...rights...are not mere gifts or vavour...for which gratitude is the sole fitting response. A right is something that can be demended or insisted upon without embarrasement or shame... A word with claim-right is one wich all persons, as actual or potential claimants, are dignified objects of respect...No amount of love ar compassion, orabedience to higher autority, or noblesse oblige, can substitute for those values.

Human existence as a social being is to realize its natural rights in order to achieve its life goals, so that the human community incorporated in community groups has the function and task of realizing conditions that are able to optimize the rights of every citizen in order to achieve personal integrity. Optimization of all wills in a community cannot be carried out in an orderly and orderly manner without the existence of mutually agreed values to regulate, organize and limit the performance of each member in the community. This is the initial process of the formation of law in society, so that the exact expression of Ubi societas ibi ius was first introduced by Marcus Tullius Cicero (106-43 BC), a philosopher, legal expert, and political expert born in Rome, about the flow of interaction in society and formation legal structure leads to the conclusion that every society absolutely adheres to the law, whether intentional or not[3]

There are three principles of state life that are interrelated and born of a political philosophy after the enlightenment era, namely democracy, the rule of law, and the protection of human rights[4]

In a democratic system, the administration of the state must rely on people's participation and interests. The implementation of the rule of law must be supported by a democratic system, between state law and democracy that cannot be separated. Democracy without legal regulation will lose form and direction, while law without democracy will lose meaning[5]. This view is in line with Magnis Suseno's opinion which states that democracy which is not a state of law is not a real democracy. Democracy is the safest way to maintain control over the rule of law[6]

The actualization of the regulation on human rights in the constitution is a real correlation between the principles of law, democracy and human rights, a legal state that relies on a democratic system is called a democratic law state (democratische rechstaat) which is a further development of constitutional democracy. It is called a democratic legal state because it accommodates the principles of state law and the principles of democracy. According to J.B.M, ten Berge,. Principle of the rule of law: the principle of legality, protection of human rights, the government is bound by law, the monopoly of coercion by the government to ensure law enforcement, and supervision by independent judges. While the principle of democracy: political representation, political responsibility, the dispersal of authority, supervision and control, honesty and openness of the government to the public, the people are given the possibility to raise objections[7]

Indonesia is a legal country, automatically these three things must be carried out simultaneously. This declaration was made by the nation's Pondhing father on August 17, 1945, which placed the 1945 Constitution and Pancasila as the legal umbrella for all legal rules that would be used in the order of the life of the nation and state. When examined in depth the preamble of the Preamble of the 1945 Constitution starting from the first to the fourth paragraph (four) contains abstract values about human rights, so it can be concluded that the recognition of human rights in the life of nation and state in Indonesia occupies a very special position.

Recognition of basic human values in Indonesia is not only stopped at an abstract level as enshrined in the state constitution of the 1945 Constitution, and is not only to be displayed or 
merely used as a media of manipulation to deceive the international worldview to be considered a good democracy, but the most important thing is how can these values be applied harmoniously in real life. Human rights values that are actualized in the state constitution become the spirit or spirit of the nation are lifted from the values that live and develop in people's lives long before this country was formed. So human rights in the life of the Indonesian people are not new, even though today many human rights values are transplanted from other people's ideological values.

The development of legal theory as a means of community development in Indonesia has a broader scope and scope than its own place of origin for several reasons, namely [8]: First, that in the process of legal reform in Indonesia it emphasizes legislation even though jurisprudence also plays a role, different from the situation in America where Roscoe Pound's theory was aimed at the renewal of court decisions specifically Supreme Court as the highest court. Second, that in developing in Indonesia, the public rejects the view of a mechanistic application which is based on the conception of Law a tool of social engineering which is described by the word tool which will result in a result that is not much different from the application of legism in the history of the law., but the Indonesian people interpret the law more as a means of development and are also influenced by cultural philosophical approaches from Northrop and the Policy oriented approach. Third, that the Indonesian nation actually has implemented the legal principle as a means of renewal, so that in essence the conception is born from the Indonesian people themselves based on urgent needs and are influenced by factors rooted in the history of the Indonesian people. Based on the ideas of the theory of development law.

From the background description above, there are several problems related to human rights with the product of legislation in Indonesia, namely the nature of human rights in the order of the life of the nation and state in Indonesia and human rights relations with legal products in Indonesia.

\section{Method}

The approach in this study is juridical normative so that the approach that will be used are: statute approach, conceptual approach, comparative approach, historical approach, type and source of data used in This research is secondary data, which consists of primary, secondary and tertiary legal materials obtained from books, literature, papers, journals, and other data sources.The primary data is used as a complement and support for secondary data obtained from stakeholders. secondary data using the literature approach method, which is a library research using legal library materials that support in this study. The collection of legal materials is done by means of tracing, collecting and studying conventional documents such as reading, seeing, listening, and with information technology (media internet). Data analysis technique. Secondary data in the form of primary, secondary and tertiary legal materials that have been collected are processed and analyzed using normative methods which are then presented descriptively.

\section{Results and Discussion}

The nature of human rights in the order of life of the nation and state in Indonesia.

The process of interaction between humans with one another is the possibility of violations and even deprivation of the rights of others[9]. If we trace the early history of human life from the Islamic perspective, since the presence of adam and hawa, which were descended by Allah as the first caliph on this earth. Even in the second generation of human beings, it has begun to be seen as a violation and deprivation of human natural rights carried out by the son of Adam who killed his own brother. 
According to Hamid S. Attamimi, quoting Burkens said that the rule of law (rechsstaat) is a country that places the law as the basis of state power and the implementation of such power in all its forms is carried out under the rule of law[10]. This is in line with Muktie Fadjar's view which states that the law is the "rule of the game" rules of the game that will prevent or prevent the authorities and humans from acting arbitrarily. Law is the boundaries of the freedom of individuals and authorities in every social interaction, so that the law will be a protection for public peace and justice in order to realize the welfare of human society. Without the enactment of the law and law enforcement that is true and fair in society, it will cause chaos and arbitrariness, both carried out by the state and carried out by individual humans[11].

In Indonesia the legal actualization in accordance with the feelings and awareness of the people is contained in the ideology and constitution of the 1945 Constitution of the Republic of Indonesia. The values contained in the state constitution are values that live and develop in people's lives long before this nation and state was formed. This proves that before Indonesia was proclaimed the founders of the nation had thought to include the values of recognition of human rights into the state ideology. In fact, this country stands as a form of struggle of the people who are tertidas and colonized who try to break away from the confinement and barbarity of violations and human rights violations committed by the invaders. The results of the agreement of the founding fathers can be seen from the preamble to the 1945 Constitution. In the first paragraph until the fourth paragraph (four) contains a very deep meaning relating to the recognition of human rights both in force in the country and globally.

The follow-up of the acknowledgment of human rights is accommodated in the articles of the 1945 Constitution. This is in line with Prof. Notonagoro's view that actually in the first paragraph opening of the 1945 Constitution, contains the philosophical meaning of Indonesian human rights rooted in human rights, namely human rights brought from birth as creatures of His creation[12].

Human rights relations with legal products in Indonesia.

Talking about human rights and legislation products must find a common thread that can provide a link between the two things. The initial start to find out the relation between human rights and the product of legislation is to depart from the rule of law. The idea of a rule of law is the idea of an ideal state that is always coveted by humans so that it can be realized in reality, even though humans always fail to make it happen in real life.

In Indonesia the concept of the rule of law is clearly regulated in the state constitution of the 1945 Constitution, namely in Article 1 paragraph (3) which states that the Indonesian state is a legal state[13]. The concept of the rule of law in Indonesia is different from the concept of the rule of law that applies in other countries. The Indonesian state of law has its own characteristics and characteristics, namely placing Pancasila as the main foundation of its implementation, so that the state of Indonesian law is popularly known as the Pancasila Law State. The Pancasila Law State is a legal state that places the pacasila as a reference benchmark and guides all applicable legal rules in Indonesia, and it becomes the determinant and validity of positive legal law. Borrowing Hans Kelsen's expression of grondnorm or basic values (Pancasila is Grondnorm, (spirit / soul), law in Indonesia, so that it is not classified as part of the positive law itself. It is transedental-logic that is above positive law[14].

Recognition of human rights in the constitution as described above is a positive step for the people of Indonesia, although this has not actually shown a significant existence towards the aspirations of the Indonesian people, namely to realize a just and dignified law. The rule of law that we want to fight for or uphold in this country is a legal state in the material sense, the rule of just law, which aims to carry out physical and spiritual welfare based on the principles of law 
that are right and fair, so that the rights -The basic rights of citizens are truly respected, protected (protected), and protected (to fulfill)[15].

Building a dignified Indonesian law is nothing but placing human dignity as the center of its orientation (anthropocentric), by developing a law that has a consumer perspective, is responsive and progressive, so that the law does not deny its existential essence to humanize Indonesian people[16]. On a practical level, even though Indonesian constitutionalism always contains ideas about a rule of law with human rights, Indonesian people are still not humanized by law, even the law has not been able to empower people to live according to their dignity as humans[17]. The empirical reality proves that there are many legal products or regulations that violate the natural values of humans, so they must be judged by the Constitutional Court. Submission of a judicial review of a law or part of a law is a violation of basic human rights. According to the Chief Justice of the Constitutional Court (MK) Mahfud MD, for the past 9 years (2003-2012) the Court has canceled 322 submissions of laws. During the establishment of the Constitutional Court, there were 460 laws that were judicial review, the Constitutional Court granted 138 Acts, or about $27 \%$ of the total number of law proposals requested for a judicial review.

The characteristic of Indonesianism which has become an agreement with the people of Indonesia since it began to stand as stated in ideology and the state constitution of the 1945 Constitution has now been eroded and even removed from its own home. Consensus agreements that are characteristic of Indonesia's democracy have been displaced by the ideological values of other nations. The voting system that is identical to the slogan of one man one vote has been echoed as a form of the most democratic and ideal election after reform. The question arises whether the election based on one man one vote that generates a majority vote has been able to realize the hopes of the Indonesian people, the condition is even more chaotic, should we return to the consensus system that produces consensus which is actually a fair decision, and the most correct, if true really we recognize Pancasila as the first pillar of the life of the nation and state in RI[18]

Enforcement of constitutional rules or constitutional rules, especially those regulated in the 1945 Constitution, depends on factors outside the law, especially political factors. A healthy political system based on the high level of compliance with political ethics will greatly determine the success of the implementation of constitutional rules. Without a sound political system, the 1945 Constitution is only in the form of "a piece of paper, or dead letter"[19].

The many final results of the canceled legislation products are due to the fact that between the government and the DPR in drafting legislation from the preparatory stage until the discussion and agreement are trapped in the oligarchy of power and group interests. With such a situation and condition, the elites in power over legislation in the end did not make Pancasila as the controller of the quality of the development of legal law, especially legislation in Indonesia. Whereas in Law No. 12 of 2011 concerning the establishment of legislation (UUP3) as a change from Law No. 10 of 2004 it has been formulated that Pancasila is the source of all legal sources, even since 1966 this formula or expression has been officially used in legislation invitation in Indonesia. This can be seen in the provisions of MPRS No XX / MPRS / 1966 concerning the DPRGR Memorandom concerning the sources of legal order of the Republic of Indonesia and the order of the legislation of the Republic of Indonesia.

The above conditions occur because there are many constitutional practices that deviate from the real track as regulated in the state ideology of Pancasila and the 1945 Constitution. Bagir Manan indicated that Indonesian constitutional practices had not fully implemented the meaning or definition of the 1945 Constitution, which was actually reflected in the ideals 
contained in The 1945 Constitution, namely the ideals of popular sovereignty, the ideals of the rule of law, the ideals of the constitution and the ideals of realizing public prosperity, the intellectual life of the nation, as much as possible the prosperity of the people on the basis of social justice for all Indonesian people[20]. The various facts above bring us to some assumptions as to why the meaning of the 1945 Constitution has not been implemented properly. The first does not want to be implemented, the two do not know how to implement it. The third is impossible because the 1945 Constitution was made too ideal[21].

Seeing the above problems shows that there is a relationship between human rights, democracy and political institutions, especially the DPR, as those who have an important role in the protection of human rights. In other words, guarantees and protection of human rights will only work well, if the instruments of democracy are realized in political institutions, are able to run well and have a partisanship towards human rights. Likewise, democracy will run as it should, in the sense of substantial democracy, if the overall human rights of citizens are guaranteed, protected and fulfilled, so that the instruments of democracy work in accordance with what the people want. In this connection, the role of actors in parliament becomes very significant. The alignment of political actors in parliament is very much needed, especially in terms of establishing laws that are in line with strengthening human rights. A balance between human rights and democracy is needed, both of which depend on and relate to each other, so a legal system that protects human rights needs to be created. Political actors in parliament will give a lot of color in creating political strokes of various legal products that they produce. Are these legal products in line with efforts to protect human rights, or just the opposite, deny or limit the protection of human rights.

The role of actors in parliament is very significant. Professionalism is a decisive indicator of whether or not these political actors can carry out their functions and tasks. Moving on from the essence of people's sovereignty, political actors or people's representatives are trustworthy bearers, because of the people's inability to carry out their own sovereignty. The elements of professionalism (quality / professional status) as proposed by Abraham Flexner in his book "scool and society are used as a reference in the recruitment system of public officials in Indonesia. The elements of professionalism are[22]: 1) Individual resposibility, 2) Practical application of intellectual knowledge, 3) Atendency of self-organization, 4) Increasingy altruistic motivation.

The alignment of political actors in parliament is very much needed, especially in terms of establishing laws that are in line with strengthening human rights. A balance between human rights and democracy is needed, both of which depend on and relate to each other, so a legal system that protects human rights needs to be created. Political actors in parliament will give color to create diverse political strokes to the legal products they produce. Are these legal products in line with efforts to protect human rights, or just the opposite, deny or limit the protection of human rights.

The House of Representatives will determine policy choices so that quality and professionalism must indeed be mandatory for every legislative member, as a supporting factor in carrying out their functions and duties, especially related to the legislative function. Are all policies made capable of empowering the spirit of promoting human rights, or even hampering efforts to uphold human rights. The extent to which the DPR's partiality towards the promotion of human rights can be measured by how much the human rights perspective and paradigm is implied and explicit in its product policy. Then, as a manifestation of the people's representatives, the DPR should also play an important role in creating public awareness about the importance of the promotion, fulfillment and enforcement of human rights. 
It was at this point that the DPR as the legislator and law with the President was required to bring up his active role. It should be, the DPR which is a representation of the people of Indonesia, who wants to be guaranteed and fulfilled their human rights as citizens, becomes the initiator in every step of the effort to promote and uphold human rights. The formation of national law and the ratification of the international human rights covenant become national law, requiring the active role of the DPR. Not just waiting for the proposed discussion from the government. The legislative products produced by the DPR are directed to no longer burden citizens with obligations, but rather strengthen efforts to fulfill citizens' rights. The relation between the state and its citizens which has been built on the perspective of obligations, should have been reconstructed using a rights perspective.

The work of the DPR certainly does not stop at the point of legal formation. The authority of the DPR to monitor government performance in implementing the law makes it important to monitor the extent of state responsibility in fulfilling the rights of its citizens. The fulfillment of human rights must be placed as a state obligation, which should not be deviated at all. Therefore the active role of the DPR in this action is important to be realized soon. Taking into account the important position of the DPR in the promotion and protection of human rights, through this set of functions, then a mechanism for monitoring and evaluating the performance of the DPR is needed in relation to human rights. This monitoring is important, in addition to ensuring the extent to which DPR products are in line with human rights, it also serves as an effort to strengthen parliamentary human rights capacity.

As actors in determining colors and the quality of rules or laws in a country, legislators must be made up of people who are qualifeld in all aspects. In Indonesia, after the amendment to the 1945 Constitution the authority of the legislature is very broad. The magnitude of the authority of the legislature becomes a magnet for everyone to be able to be part of the institution, even people are no longer able to reflect in measuring themselves about standards of appropriateness and feasibility. They only think that all people have the same rights as long as they can meet the formal standards and criteria offered in the legislation. Material, money, popularity become the main energy that launches someone to enter the house of the people's representatives.

Moral responsibility as a link and the taste adhesive between those that are represented and those that represent are lost when the sound value has been replaced by rewards in the form of material and money. Ethical values, morals, quality are no longer meaningful things that will be used as benchmarks by the people in making choices. Simply put, the requirements and the ease of the recruitment process of candidates as they are now make the legislature an arena for political competition that is not classy and not authoritative. Fighting fist, blasphemy with indecent words that are published in various print and electronic media has become a very common thing to happen. Likewise, various legal cases involving public officials are no exception to people's representatives, both in cases of corruption, sexual abuse, violence and various other legal cases. Borrowing country nicknames, shortcuts[23]. then it is appropriate for all conditions that occur at this time.

The end of all these processes and conditions will give birth to poor quality representatives who impact on their functions and duties that will not work properly. The rise of expert staff appointments at the level of commissions, factions, and even individuals has proven that our legislative members have not been able to carry out their functions and duties independently due to various limitations they have. The legislative function which is the main authority of the legislative body is only used as a venue for the translation of articles based on orders and desires of groups and certain parties whose values are determined in the standards of political dowry both individually and in congregation. It is very ironic if we look at it from normal glasses. But this condition is considered normal and reasonable, because the concept of nawaitu 
as I pointed out at the beginning of this paper is indeed far off the mark. Between das sain and das sollen lies a distance that is impossible to reach. The farther the distance and the more winding road becomes the main barrier to the realization of the noble ideals of the people of Indonesia.

\section{Conclusion}

Human rights are the basic rights possessed by every human being and have emerged since humans began to recognize association. Human rights are not gifts and gifts that can be deprived and revoked, even though someone has acted ruthlessly and cruelly, but these basic rights cannot be implemented freely and totally in everything, because these basic rights are also limited by the individual rights of others. These restrictions are made in the form of formal legal rules which are the main tasks of the legislature. As the main actor determining the color of the law, the legislative members must be composed of selected people and qualified to be able to their functions and duties properly. At present ideal conditions are still far from expectations, this is due to various internal and external factors related to the institution. The institution's recruitment system in the future must be perfected so that it is able to work as expected, which is able to realize the ideals of the people of Indonesia and be able to create quality legal products that are in harmony with the carry out hopes and aspirations of the people.

\section{References}

[1] PUSHAM UII.2015.Hukum dan Hak Asasi Manusia sebuah Bunga Rampai, Yogyakarta: p.11

[2] Peter Mahmud Marzuki.2009. Pengantar Ilmu Hukum, Kencana Prenada Media Group, Jakarta:p.179

[3] http://www.kompasiana.com/afsee/ubi-societas-ibi-ius-dan-etika-netizen, Kamis 19 Mei, 2018

[4] Mahfud MD, Diskusi Ilmiah tentang. 1994." Perlindungan HAM dalam Sistem Hukum Indonesia- Pusat Antar Universitas-Pusat Study Sosial-, Universitas Yogyakarta. 18 Oktober 1994.

[5] Ridwan AR, Hukum Adminisrasi Negara, PT Rajagrafindo Persada, Jakarta, 2008, Hm-8

[6] Frans Magnis Suseno.1997. Mencari sosok Demokrasi Sebuah Telaah Filosofis, Gramedia, Jakarta, p.58

[7] Ridwan AR.2008.Hukum Adminisrasi Negara, PT Rajagrafindo Persada, Jakartap.9-10

[8] Otje Salman dan Eddy Damian,Otje Salman dan Eddy Damian,1987. Konsep-Konsep Hukum dalam Pembangunan, Bandung : Alumni, p. 83-85

[9] AM, Fatwa, Hak Asasi Manusia, 1997. Pluralisme Agama, dan Ketahanan Nasional, dalam HAM dan Pluralisme Agama Sebuah Bunga Rampai, Pusat Kajian Strategi dan Kebijakan (PKSK), Surabaya,p.28.

[10] A Hamis S. Attamimi, Teori Perundang-undangan Indonesia, makalah pada Pidato upacar Pengukuhan Guru Besar Tetap di fakultas Hukum UI, Jakarta, 25 April 1992, p-8

[11] Hariyono dkk, 2013. Membangun Negara Hukum yang Bemartabat, Sentra Press, Malang, p-2.

[12] Demokrasi HAM dan Konstitusi Perspektif Negara-bangsa untuk Mengadirkan Keadilan, Bunga Rampai, Setara Press, TT Malang, p16

[13] UUD Republik Indonesia Tahun 1945 (Pasca amandemen)

[14] Hans Kelsen, dalam Bernard L Tanya Dkk, dalam Pancasila Bingkai Hukum Indonesia,Genta Publishing, Yogyakarta, 2015, p-13

[15] Abdul Mukthie Fadjar,2013. Perjuangan untuk Sebuah Negara Hukum yang Bermartabat, Hariyono dkk, Membangun Negara Hukum yang Bemartabat, Sentra Press, Malang, 2013, p.5 
[16] Abdul Mukthie Fadjar, 2013. Perjuangan untuk Sebuah Negara Hukum yang Bermartabat Hariyono dkk, Membangun Negara Hukum yang Bemartabat, Sentra Press, Malang, p- 7

[17] Abdul Mukthie Fadjar, Perjuangan untuk Sebuah Negara Hukum yang Bermartabat Hariyono dkk, Membangun Negara Hukum yang Bemartabat, Sentra Press, Malang, 2013, p. 7

[18] Sunaryati Hartono, Hidupkan Kembali Pengajaran dan Penelitian Hukum Laut, dalam Peran Hukum dalam Pembangunan di Indonesia p. 7

[19] Bagir Manan, Susi Dwi Harijanti, 2014. Memahami Konstitusi Makna dan Aktualisasi, PT Grafindo Perda Jakarta, p-189.

[20] Bagir Manan, Susi Dwi Harijanti,2014. Memahami Konstitusi makna dan Aktualisasi, PT Grafindo Perda Jakarta.p-184.

[21] Bagir Manan, Susi Dwi Harijanti, 2014.Memahami Konstitusi makna dan Aktualisasi, PT Grafindo Perda Jakarta. p-184

[22]. Dewa Gde Atmadja dkk,2011. Demokrasi Ham dan Konstitusi, Perspektif Negara Bangsa untuk Menghadikan Keadilan, Setara Press, Malang, p- 48

[23] Media Indonesia, 3 Juli 2013 